Dunamis: Jurnal Teologi dan Pendidikan Kristiani

Volume 3, Nomor 2 (April 2019)

ISSN 2541-3937 (print), 2541-3945 (online)

http://www.sttintheos.ac.id/e-journal/index.php/dunamis

Submitted: 3 April 2019

Accepted: 26 April 2019

Published: 29 April 2019

\title{
Upaya Meningkatkan Sikap Solidaritas dan Hasil Belajar dengan Menggunakan Media Grafis "Monas Mama"
}

\author{
Rifai \\ SMPN 17 Surakarta \\ kangmasrifai@gmail.com
}

\begin{abstract}
This study aimed to prove the increasing of solidarity and learning outcomes in the class of Christian Religious Education and Good Character through the use of the graphical media "Monas Mama." The strategy in this research was carried out through 2 moderate cycles to improve the attitude of solidarity and learning outcomes using the graphic media "Monas Mama." The results obtained from this study that through the use of the graphic media "Monas Mama" there was an increase in student solidarity and student learning outcomes. From the results it could be concluded that the use of graphic media not only could stimulate students' cognitive, but could also help foster students' character.
\end{abstract}

Keywords: solidarity; learning outcome

\begin{abstract}
Abstrak
Penelitian ini bertujuan membuktikan adanya peningkatan sikap solidaritas dan hasil belajar dalam pembelajaran Pendidikan Agama Kristen dan Budi Pekerti melalui penggunaan media grafis "Monas Mama". Strategi dalam penelitian ini dilakukan melalui 2 siklus sedang untuk meningkatkan sikap solidaritas dan hasil belajar menggunakan media grafis "Monas Mama". Hasil yang diperoleh dari penelitian ini bahwa melalui penggunaan media grafis "Monas Mama" terjadi peningkatan sikap solidaritas siswa dan hasil belajar siswa. Dari hasil penelitian ini maka dapat disimpulkan bahwa penggunaan media grafis tidak hanya dapat merangsang peningkatan aspek kognitif siswa, namun juga dapat membantu menumbuhkan budi pekerti siswa.
\end{abstract}

Kata kunci: solidaritas; hasil belajar; Monas Mama 


\section{PENDAHULUAN}

Pendidikan Agama Kristen dan Budi Pekerti yang diajarkan dalam kelas merupakan kegiatan belajar mengajar yang bersumber dari kebenaran Alkitab adalah firman Tuhan. Kebenaran Alkitab sebagai dasar utama dalam pembelajaran Pendidikan Agama Kristen dan Budi Pekerti membentuk siswa siswi kristiani sebagai manusia dewasa yang seutuhnya. Sairin mengatakan bahwa pendidikan Kristen memiliki visi membentuk manusia secara utuh sebagai ciptaan Allah yang dewasa rohani serta mampu bertumbuh dan menjalankan tugasnya secara bertanggungjawab kepada Allah, manusia dan masyarakat. ${ }^{1}$

\section{Ini berarti bahwa Pendidikan} Agama Kristen dan Budi Pekerti berusaha membentuk pribadi-pribadi kristiani yang bertanggung jawab kepada manusia terlebih lagi kepada Tuhan. Salah satu bentuk tanggung jawab kepada manusia yang menjadi bahasan dalam Pendidikan Agama Kristen dan Budi adalah sikap solidaritas dalam masyarakat majemuk. Dalam Lampiran 32 Peraturan Menteri Pendidikan dan Kebudayaan RI Nomor 24 Tahun 2016 khususnya KD 1.3. Menghayati arti peduli dan solidaritas bagi

\footnotetext{
${ }^{1}$ Weinata Sairin, "Peran Pendidikan Agama Kristen Dalam Nafas PP 55 Tahun 2007," Buletin BSNP (Jakarta, March 2012), 7.
}

sesama. Untuk KD 2.3. Mau menghargai sesama sebagai wujud solidaritas dan untuk KD 3.3. Menceritakan bentuk solidaritas sosial yang dilakukan bagi sesama dan yang terakhir KD 4.3. Membiasakan diri bersikap solider terhadap sesama dalam berbagai bentuk dan cara.

Pada kenyataannya masih didapati adanya siswa kurang menghargai perbedaan satu dengan lainnya. Sebagai contoh adanya siswa yang kurang menghargai pendapat teman yang berbeda denominasi gereja dengan rata-rata sebesar $61 \%$. Berarti sikap solidaritas siswa terhadap teman yang berbeda aliran gereja masih tergolong kurang, mengingat sikap solidaritas penting dalam hidup berdampingan satu dengan lainnya. Kendala yang didapati dalam kelas berkenaan dengan daya serap makna pengetahuan yang wajib diterapkan dalam kehidupan sehari-hari secara otomatis mempengaruhi capaian hasil belajar siswa. Keberhasilan siswa mencapai hasil belajar dari 14 siswa yang mengikuti pembelajaran hanya 8 siswa yang dinyatakan berhasil atau sebesar 57\% sedangkan sisanya 6 siswa atau sebesar $43 \%$ dinyatakan belum tuntas.

Tentu saja ini perlu mendapatkan perhatian dari guru dikarenakan hampir separuh kelas siswa dinyatakan tidak 
tuntas dalam belajar. Media pembelajaran yang cocok untuk digunakan dalam kegiatan belajar mengajar dalam membangun sikap solidaritas di tengah masyarakat majemuk yaitu "Monas Mama." Media grafis "Monas Mama" ini merupakan media pembelajaran yang mengadopsi permainan populer monopoli. Rudi dan Cepti menjelaskan yang dimaksud dengan media grafis adalah media visual yang menyajikan fakta, ide atau gagasan melalui penyajian kata-kata, kalimat angka, dan simbol atau gambar. ${ }^{2}$ Grafis biasanya digunakan untuk menarik perhatian, memperjelas sajian ide, dan mengilustrasikan fakta-fakta sehingga menarik dan diingat orang.

Berdasarkan permasalahan dan dasar pemikiran di atas, penulis hendak membuktikan sebagai berikut: Pertama, penggunaan "Monas Mama" dapat meningkatkan solidaritas di tengah masyarakat majemuk siswa kelas 7 SMP Negeri 17 Surakarta Semester 2 Tahun Pelajaran 2017/2018. Kedua, Penggunaan "Monas Mama" dapat meningkatkan hasil belajar Membangun Solidaritas di Tengah Masyarakat Majemuk siswa kelas 7 SMP Negeri 17 Surakarta Semester 2 Tahun Pelajaran 2017/2018. Melalui penelitian

\footnotetext{
${ }^{2}$ Rudi Susilana and Cepti Riyana, Media Pembelajaran Hakikat, Pengembangan, Pemanfaatan Dan Penilaian (Bandung: CV. Wacana Prima, 2009), 14.
}

ini diharapkan mampu meningkatkan sikap solidaritas siswa di tengah masyarakat yang majemuk. Selain itu juga melalui penggunaan media grafis "Monas Mama" diharapkan mampu meningkatkan solidaritas dan hasil belajar.

\section{METODE PENELITIAN}

Instrumen penelitian yang digunakan dalam penelitian ini adalah instrumen tes dan non tes. Instrumen non tes dilakukan dengan menggunakan observasi, wawancara dan dokumen. Lembar observasi guna merekam atau mengamati kegiatan guru dan peserta didik pada saat proses pembelajaran dilakukan. Lembar wawancara guna merekam ataupun mengumpulkan data pelengkap dari hasil observasi ataupun dokumen. Teknik tes tertulis digunakan untuk mengumpulkan data peserta didik yang berhubungan dengan penguasaan materi yang telah diajarkan oleh guru.

Teknik pemanfaatan dokumen sebagai sumber data peneliti sering dikenal dengan istilah content analysis. ${ }^{3}$ Teknik pengumpulan data berupa dokumen untuk mencatat semua arsip dan dokumen berupa foto-foto kegiatan, daftar hadir peserta didik, prestasi belajar peserta didik, dan

\footnotetext{
${ }^{3}$ Lexy Moleong, J, Metodologi Penelitian Kualitatif (Bandung: PT. Remaja Rosdakarya, 2006), 220.
} 
dokumen-dokumen yang berkaitan dengan penelitian tindakan kelas ini.

Menurut Hamidi mengemukakan observasi berarti peneliti melihat dan mendengarkan (termasuk menggunakan tiga indra yang lain) apa yang dilakukan dan dikatakan atau diperbincangkan para responden dalam aktifitas kehidupan sehari-hari baik sebelum, menjelang, ketika dan sesudahnya. ${ }^{4}$ Dalam pelaksanaan observasi dilaksanakan secara langsung, terfokus dan selektif. Agar observasi dapat lebih efektif maka dilengkapi dengan format atau blangko pengamatan. $^{5}$

Dalam instrumen observasi, penelitian berusaha mengumpulkan data berupa sikap solidaritas siswa di kelas maupun di luar kelas, kegiatan belajar siswa selama di kelas maupun di luar kelas, prestasi belajar siswa, proses kegiatan belajar mengajar yang dilaksanakan oleh guru dan interaksi antara siswa dengan rekan kelas dan siswa dengan guru.

Moleong mengatakan wawancara adalah percakapan dengan maksud tertentu. $^{6}$ Wawancara dapat dilakukan

\footnotetext{
${ }^{4}$ Hamidi, Metode Penelitian Kualitatif: Aplikasi Praktis Pembuatan Proposal Dan Laporan Penelitian (Malang: UMM PRESS, 2005), 74.

${ }^{5}$ Suharsimi Arikunto, Prosedur Penelitian Suatu Pendekatan Praktek (Jakarta: Rineka Cipta, 2012), 229.

${ }^{6}$ Moleong, J, Metodologi Penelitian Kualitatif, 135.
}

secara terstruktur maupun tidak terstruktur, dan dapat dilakukan melalui tatap muka (face to face) maupun menggunakan telepon. ${ }^{7}$ Dalam teknik wawancara ini peneliti hendak mengumpulkan bukti-bukti penggunaan media belajar yang berupa media grafis "Monas Mama."

Data yang tersaji dalam penelitian ini dianalisis secara kuantitatif dan kualitatif. Analisa data secara kuantitatif untuk mengetahui ada penggunaan media belajar yang berupa media grafis "Monas Mama" untuk meningkatkan sikap solidaritas dan prestasi belajar materi membangun solidaritas di tengah masyarakat yang majemuk bagi siswa.

Sedangkan untuk analisa kualitatif, data dari berbagai sumber dengan menggunakan teknik pengumpulan data yang bermacam-macam (triangulasi), dan dilakukan secara terus-menerus sampai datanya jenuh. Dengan pengamatan yang terus menerus tersebut mengakibatkan variasi data tinggi sekali. Data yang diperoleh pada umumnya adalah data kualitatif. $^{8}$

Indikator keberhasilan Penelitian Tindakan Kelas ini yaitu apabila terjadi peningkatan $85 \%$ sikap solidaritas dan prestasi belajar materi membangun

\footnotetext{
${ }^{7}$ Sugiyono, Metode Penelitian Kuantitatif, Kualitatif Dan Research \& Defelopment (Bandung: Alfabeta, 2013), 157.

${ }^{8}$ Ibid, 333.
} 
solidaritas di tengah masyarakat yang majemuk. Keberhasilan pencapaian prestasi belajar ditandai dengan meningkatnya nilai yang diperoleh peserta didik pada hasil tes dan tes formatif materi membangun solidaritas di tengah masyarakat yang majemuk dengan Ketuntasan Belajar Minimal (KBM) 75 serta terdapat perubahan perilaku solidaritas siswa baik di dalam maupun di luar kelas.

\section{HASIL DAN PEMBAHASAN}

Hidup di tengah berbagai perbedaan perlu mengembangkan sikap toleran, empati, dan simpati haruslah terus dibangun sebagai pra syarat eksistensi keragaman yang ada. Masyarakat Indonesia merupakan masyarakat yang heterogen baik secara agama, suku, ras dan budaya. Siswa yang belajar PAK dan Budi Pekerti harus menjalani proses belajar untuk hidup bersama dengan orang lain yang memiliki latar belakang hidup dan agama yang berbeda. Sikap saling menghargai adalah menjunjung tinggi harkat dan martabat kesetaraan. Menghargai sesama manusia adalah sifat dasar yang diajarkan semua agama. Bagi penulis penanaman nilai-nilai solidaritas begitu sangat penting sekali dikarenakan siswa siswi yang berinteraksi di kelas maupun sekolah dengan sesamanya yang beragam budaya ataupun adat. Keberagaman ini menuntut setiap pribadi untuk menjaga kerukunan satu dengan lainnya.

Penelitian yang dilaksanakan di SMP Negeri 17 Surakarta dengan menggunakan media grafis Monas Mama pada siswa kelas 7 untuk meningkatkan solidaritas dan hasil belajar. Hasil penelitian diuraikan dengan data kemampuan kondisi awal sebelum dilaksanakan tindakan dan setelah dilakukan tindakan. Pelaksanaan tindakan kelas dilakukan dalam materi membangun solidaritas ditengah masyarakat majemuk. Penelitian dilaksanakan sebanyak dua siklus yang terdiri dari dua kali pertemuan yang dilaksanakan sesuai jadwal pelajaran PAK dan Budi Pekerti.

Proses belajar membangun solidaritas di tengah masyarakat majemuk dengan menggunakan Monas Mama menjadikan siswa antusias dan tertarik untuk mengikuti pelajaran. Secara proses mengalami peningkatan dapat dilihat dari peningkatan keaktifan, keterlibatan dan antusias siswa dalam mengikuti pembelajaran. Siswa lebih komunikatif dengan guru dan merasakan senang selama pembelajaran berlangsung. Siswa memberikan respon yang baik, aktif dalam pembelajaran, percaya diri dalam menyampaikan pendapat/menjawab 
pertanyaan guru dan bertanya tentang materi.

Guru memiliki peran utama dalam Penanaman sikap solidaritas sangat penting ddiajarkan kelas, seperti yang diungkapkan dalam penelitian Yopi, Sulistyarini, dan Asriati mengungkapkan peran guru sebagai motivator dalam membina solidaritas sosial. ${ }^{9}$ Guru memberikan penilaian pada hasil kerja siswa baik tugas individu maupun kelompok, memberi pujian bagi siswa yang menjawab pertanyaan dari guru dengan baik dan benar. Dengan cara menegur siswa yang tidak mengerjakan tugas kelompok, menegur siswa yang berbicara dengan temannya saat yang lain belajar, menegur siswa yang memainkan handphone saat jam belajar. Artinya melalui penelitian ini dapat dipetik sebuah pelajaran bahwa dalam membina solidaritas sosial siswa dengan cara memberikan reward and punishment terbukti mampu membentuk sikap solidaritas siswa di sekolah.

Sedangkan Nafiah mengatakan bahwa penguasaan standar kompetensi menampilkan perilaku sesuai nilai-nilai Pancasila harus dilakukan dalam

\footnotetext{
${ }^{9}$ Vinsensius Yopi, . Sulistyarini, and Nuraini Asriati, "PERAN GURU DALAM MEMBINA SOLIDARITAS SOSIAL SISWA KELAS XI IPS KUALA MANDOR B," Jurnal Pendidikan dan Pembelajaran 5, no. 2 (February 25, 2016), accessed April 24, 2019 http://jurnal.untan.ac.id/index.php/jpdpb/article/vie w/14003.
}

kehidupan sehari-hari, yakni salah satunya adalah untuk menghormati orang lain untuk menjaga solidaritas sosial. $^{10}$ Dikarenakan hal tersebut ternyata memang saling berhubungan dimana penguasaan standar kompetensi menampilkan perilaku yang sesuai nilai-nilai Pancasila dapat mempengaruhi solidaritas sosial siswa.

Dalam penyelenggaraan Pendidikan Agama Kristen di sekolah perlu terdapat unsur-unsur utama dalam pembelajaran, yaitu guru, peserta didik, kurikulum, strategi dan metode pembelajaran, materi, sarana dan prasarana, pembiayaan, serta evaluasi. Unsur-unsur inilah menjadi penentu keberhasilan dalam penyelenggaraan Pendidikan Agama Kristen di sekolah. Jika ada diantara unsurunsur tersebut tidak memenuhi standar, maka menyebabkan terganggunya pencapaian tujuan tersebut. Sebagai contoh metode pembelajaran yang masih monoton, sarana prasarana yang tidak mendukung, guru yang kurang kreatif, serta karakteristik peserta didik yang beragam.

Salah satu faktor penunjang keberhasilan kegiatan belajar mengajar di

\footnotetext{
${ }^{10}$ Arifatun Nafiah, HUBUNGAN PENGUASAAN STANDAR KOMPETENSI MENAMPILKAN PERILAKU YANG SESUAI NILAI- NILAI PANCASILA DENGAN SOLIDARITAS SOSIAL PADA SISWA KELAS VIII MTS NEGERI 1 SURAKARTA TAHUN AJARAN 2009/2010, 2010, accessed April 24, 2019, https://eprints.uns.ac.id/6574/.
} 
kelas adalah pemanfaatan media pembelajaran secara maksimal. Untuk itu dalam menetapkan media pembelajaran supaya guru memperhatikan jenis mata pelajaran yang diampunya. Zainiyati menjelaskan media pembelajaran merupakan bagian integral dari sistem pembelajaran. $^{11}$ Media pembelajaran merupakan sarana proses komunikasi interaksi kegiatan pembelajaran aktif antara guru dan siswa.

$$
\text { Selanjutnya dijelaskan oleh }
$$

Ngainun bahwa proses pembelajaran pada hakikatnya merupakan proses komunikasi, penyampaian pesan dari pengantar ke penerima. $^{12}$ Pesan yang disampaikan, berupa isi atau ajaran yang dituangkan ke dalam simbol-simbol komunikasi, baik verbal (kata-kata dan tulisan) maupun non verbal. Pesan komunikasi baik verbal maupun nonverbal untuk itu diperlukan media pembelajaran.

Safei mengungkap empat fungsi media grafis sebagai berikut: (1) untuk menarik perhatian supaya minat dan perhatian meningkat sehingga siswa aktif memperhatikan dan termotivasi mempelajari selanjutnya; (2) untuk

\footnotetext{
${ }^{11}$ Husniyatus Salamah Zainiyati, Pengembangan Media Pembelajaran Berbasis ICT, Konsep Dan Aplikasi Pada Pembelajaran Pendidikan Agama Islam (Bandung: PT Kharisma Putra Utama, 2017), 34-35.

${ }^{12}$ Ngainun Naim, Dasar-Dasar Komunikasi

Pendidikan (Yogyakarta: Ar-Ruzz, 2010), 27.
}

memperjelas ide pikiran yang abstrak dapat ditangkap dengan jelas oleh siswa; (3) memperkenalkan ide pikiran baru yang sulit untuk dibayangkan; (4) memperkuat daya ingat terhadap suatu stimulus sehingga tidak mudah dilupakan ${ }^{13}$

Hal tersebut membuktikan penggunaan media grafis "Monas Mama" memberikan pengaruh terhadap suasana pembelajaran di kelas. Dalam penelitian ini penerapan media grafis terbukti membantu meningkatkan proses pembelajaran. Selain itu juga membuktikan keuntungan menggunakan media grafis Monas Mama. Seperti penelitian Zainiyati menjelaskan media grafis merupakan bagian integral pembelajaran. Media grafis sebagai sarana proses komunikasi interaksi kegiatan pembelajaran aktif antara guru dan siswa. Salah satu faktor penunjang keberhasilan kegiatan belajar adalah pemanfaatan media grafis secara maksimal. ${ }^{14}$

Lebih lanjut Ngainun menjelaskan proses pembelajaran merupakan proses komunikasi menyampaikan pesan dari pengantar ke penerima. $^{15}$ Pesan

\footnotetext{
${ }^{13}$ Safei Safei, "PENGGUNAAN MEDIA GRAFIS DALAM PROSES PEMBELAJARAN," Lentera Pendidikan : Jurnal Ilmu Tarbiyah dan Keguruan 10, no. 1 (June 23, 2007): 107-115, accessed April 24, 2019, http://journal.uinalauddin.ac.id/index.php/lentera_pendidikan/article/ view/3728.

${ }^{14}$ Zainiyati, Pengembangan Media Pembelajaran Berbasis ICT, Konsep Dan Aplikasi Pada Pembelajaran Pendidikan Agama Islam.

${ }^{15}$ Naim, Dasar-Dasar Komunikasi Pendidikan.
} 
komunikasi berupa verbal maupun non verbal diperlukan media pembelajaran berupa media grafis. Pesan komunikasi dengan menggunakan media grafis meningkatkan proses pembelajaran dan hasil belajar. Hal senada juga diungkapkan oleh Rudi dan Cepti bahwa media dapat mengakomodasi potensi indera setiap peserta didik sehingga proses dan hasil belajar meningkat. ${ }^{16}$

Riyana media sebagai alat bantu sekaligus juga memiliki fungsi penyalur pesan. ${ }^{17}$ Dale's Cone Experience (Kerucut Pengalaman Dale) sebagai dasar penggunaan media dalam kegiatan belajar.

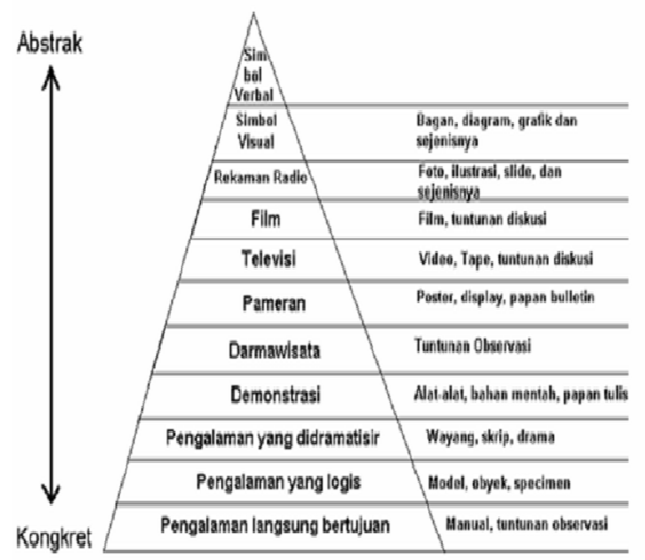

Gambar 1. Kerucut Pengalaman Egdar Dale $^{18}$

\footnotetext{
${ }^{16}$ Susilana and Riyana, Media Pembelajaran Hakikat, Pengembangan, Pemanfaatan Dan Penilaian, 100.

${ }^{17}$ Cepi Riyana, Media Pembelajaran (Jakarta: Jenderal Pendidikan Islam Kementerian Agama RI, 2012), 12.

${ }^{18}$ Guslinda and Rita Kurnia, Media Pembelajaran Anak Usia Dini (Surabaya: Jakad Publishing, 2018), 4.
}

Dari bagan menunjukkan bahwa informasi pengalaman langsung menyajikan pengalaman belajar secara lebih kongkret. ${ }^{19}$ Monas mama membimbing siswa memahami nilai-nilai solidaritas secara langsung sehingga siswa memahami makna dan pengetahuan tentang membangun sikap solidaritas di tengah masyarakat majemuk.

Melalui media grafis "Monas Mama”, siswa dibimbing untuk memahamai nilai-nilai solidaritas di tengah masyarakat majemuk yang bersumber dari Alkitab. Dengan demikian siswa semakin memahami Allah sebagai kebenaran yang tertuang dalam Alkitab dan diimplementasikan dalam kehidupan praktis sehari-hari. $^{20}$

Media grafis "Monas Mama" menjadikan siswa memahami makna dan pengetahuan tentang membangun sikap solidaritas di tengah masyarakat majemuk. Makna dan pengetahuan tentang sikap solidaritas dituangkan dalam bentuk katakata, simbol atau gambar serta gagasan yang mengilustrasikan solidaritas di tengah masyarakat majemuk.

\footnotetext{
${ }^{19}$ Ibid.

${ }^{20}$ Kevin Tonny Rey, "Khotbah Pengajaran Versus Khotbah Kontemporer," DUNAMIS: Jurnal Penelitian Teologi dan Pendidikan Kristiani 1, no. 1 (September 1, 2016): 31, accessed March 8, 2018, http://sttintheos.ac.id/e-

journal/index.php/dunamis/article/view/100.
} 
Perilaku solidaritas siswa seperti gotong royong, bekerja sama, menghargai perbedaan, menghargai penganut agama lain, berteman tanpa memandang perbedaan, menolong sesama tanpa memandang perbedaan patut dikembangkan dalam pembelajaran membangun solidaritas di tengah masyarakat majemuk. Dari hasil penelitian perihal solidaritas dapat dilihat tabel di bawah ini:

Tabel 1. Peningkatan Solidaritas

\begin{tabular}{cccc}
\hline \multicolumn{3}{c}{ Solidaritas Siswa } \\
\hline Penilaian & $\begin{array}{c}\text { Kondisi } \\
\text { Awal }\end{array}$ & $\begin{array}{c}\text { Siklus } \\
\text { I }\end{array}$ & Siklus II \\
\hline $\begin{array}{c}\text { Penilaian } \\
\text { Siswa }\end{array}$ & $61 \%$ & $72 \%$ & $86 \%$ \\
$\begin{array}{c}\text { Penilaian } \\
\text { Guru }\end{array}$ & $63 \%$ & $74 \%$ & $85 \%$ \\
Rata-rata & $62 \%$ & $73 \%$ & $86 \%$ \\
\hline
\end{tabular}

Sedangkan Untuk pencapaian hasil belajar seperti tabel di bawah ini:

Tabel 2. Rata-rata Hasil Belajar

\begin{tabular}{ccc}
\hline \multicolumn{3}{c}{ Hasil Belajar Siswa } \\
\hline Kondisi Awal & Siklus I & Siklus II \\
\hline $57 \%$ & $71 \%$ & $93 \%$ \\
\hline
\end{tabular}

Peningkatan hasil belajar nilai ratarata hasil belajar dari kondisi awal, siklus I dan siklus II menggunakan media grafis Monas Mama dapat dinyatakan berhasil. Pencapaian belajar tidak dapat dilepaskan dari upaya guru dalam meningkatkan keterampilan mengajar. Hadirnya Monas Mama merupakan bentuk pengembangan keterampilan guru dalam usaha meningkatkan hasil belajar. Ditegaskan oleh Yaumi bahwa guru perlu memiliki keterampilan memadai dalam mendesain, mengembangkan, dan memanfaatkan media pembelajaran sebagai upaya meningkatkan minat, perhatian, motivasi dan hasil belajar. ${ }^{21}$

Monas Mama memberikan stimulus positif bagi siswa dalam peningkatan kemampuan dan hasil belajar. Yaumi mengutip pendapat Rapidbe (2012) perihal dampak aktivitas pembelajaran seperti di bawah ini: (1) 10\% dari apa yang dibaca; (2) $20 \%$ dari apa yang didengar; (3) $30 \%$ dari apa yang dilihat; (4) $50 \%$ dari apa yang dilihat dan didengar; (5) 70\% dari apa yang ditulis dan didengar; dan (6) $90 \%$ dari apa yang dikatakan dan dilakukan

Monas Mama memberikan pengalaman yang menarik bagi peserta didik, dimana peserta didik bukan hanya melihat dan membaca. Melainkan peserta didik juga mendengar, mengatakan sekaligus melakukan setiap perintah yang berisi materi membangun solidaritas di tengah masyarakat majemuk. Dengan demikian peserta didik memiliki kemampuan menyerap materi dengan baik sehingga hasil belajarnya mengalami peningkatan yang baik.

\footnotetext{
${ }^{21}$ Muhammad Yaumi, Media Dan Teknologi Pendidikan (Jakarta: Prenadamedia, 2018), 13.
} 


\section{KESIMPULAN}

Hasil dari penelitian ini adalah: pertama, melalui penggunaan Monas Mama dapat meningkatkan solidaritas di tengah masyarakat majemuk siswa kelas 7 SMP Negeri 17 Surakarta Semester 2 Tahun Pelajaran 2017/2018. Kedua, melalui penggunaan Monas Mama dapat meningkatkan hasil belajar Membangun Solidaritas di Tengah Masyarakat Majemuk siswa kelas 7 SMP Negeri 17 Surakarta Semester 2 Tahun Pelajaran 2017/2018. Ini sesuai dengan persentase hasil belajar siswa dari siklus I sebesar 71\% pada siklus II menjadi 93\%. Dengan demikian dapat disimpulkan bahwa penggunaan media grafis tidak hanya dapat merangsang peningkatan aspek kognitif siswa, namun juga dapat membantu menumbuhkan budi pekerti siswa.

\section{REKOMENDASI}

Melalui penelitian ini siswa siswi Kristen hendaklah meningkatkan sikap solidaritas ditengah masyarakat majemuk. Siswa siswi Kristen dalam dalam komunitas yang berbeda kepentingan, suku, agama, ras, golongan ataupun adat istiadat. Melalui penelitian ini diharapkan guru perlu meningkatkan keterampilan membuat media grafis model lainnya untuk menghadirkan suasana belajar yang menyenangkan. Melalui penelitian ini penggunaan media grafis hendaknya dapat menjadi bagian upaya mengembangkan sekolah ke arah yang lebih baik utamanya kualitas pembelajaran. Dan melalui penelitian ini sarana prasarana pembelajaran dioptimalkan agar memperlancar pembelajaran sehingga kualitas mutu pendidikan di sekolah meningkat.

\section{DAFTAR PUSTAKA}

Arikunto, Suharsimi. Prosedur Penelitian Suatu Pendekatan Praktek. Jakarta: Rineka Cipta, 2012.

Guslinda, and Rita Kurnia. Media Pembelajaran Anak Usia Dini. Surabaya: Jakad Publishing, 2018.

Hamidi. Metode Penelitian Kualitatif: Aplikasi Praktis Pembuatan Proposal Dan Laporan Penelitian. Malang: UMM PRESS, 2005.

Moleong, J, Lexy. Metodologi Penelitian Kualitatif. Bandung: PT. Remaja Rosdakarya, 2006.

Nafiah, Arifatun. HUBUNGAN PENGUASAAN STANDAR KOMPETENSI MENAMPILKAN PERILAKU YANG SESUAI NILAINILAI PANCASILA DENGAN SOLIDARITAS SOSIAL PADA SISWA KELAS VIII MTS NEGERI 1 SURAKARTA TAHUN AJARAN 2009/2010, 2010. Accessed April 24, 2019. https://eprints.uns.ac.id/6574/.

Naim, Ngainun. Dasar-Dasar Komunikasi Pendidikan. Yogyakarta: Ar-Ruzz, 2010.

Rey, Kevin Tonny. "Khotbah Pengajaran Versus Khotbah Kontemporer." DUNAMIS: Jurnal Penelitian Teologi dan Pendidikan Kristiani 1, no. 1 (September 1, 2016): 31. Accessed 
March 8, 2018.

http://sttintheos.ac.id/ejournal/index.php/dunamis/article/vie w/100.

Riyana, Cepi. Media Pembelajaran. Jakarta: Jenderal Pendidikan Islam Kementerian Agama RI, 2012.

Safei, Safei. "PENGGUNAAN MEDIA GRAFIS DALAM PROSES PEMBELAJARAN." Lentera Pendidikan : Jurnal Ilmu Tarbiyah dan Keguruan 10, no. 1 (June 23, 2007): 107-115. Accessed April 24, 2019. http://journal.uinalauddin.ac.id/index.php/lentera_pend idikan/article/view/3728.

Sairin, Weinata. "Peran Pendidikan Agama Kristen Dalam Nafas PP 55 Tahun 2007.” Buletin BSNP. Jakarta, March 2012.

Sugiyono. Metode Penelitian Kuantitatif, Kualitatif Dan Research \& Defelopment. Bandung: Alfabeta, 2013.
Susilana, Rudi, and Cepti Riyana. Media Pembelajaran Hakikat, Pengembangan, Pemanfaatan Dan Penilaian. Bandung: CV. Wacana Prima, 2009.

Yaumi, Muhammad. Media Dan Teknologi Pendidikan. Jakarta: Prenadamedia, 2018.

Yopi, Vinsensius, . Sulistyarini, and Nuraini Asriati. "PERAN GURU DALAM MEMBINA SOLIDARITAS SOSIAL SISWA KELAS XI IPS KUALA MANDOR B." Jurnal Pendidikan dan Pembelajaran 5, no. 2 (February 25, 2016). Accessed April 24, 2019. http://jurnal.untan.ac.id/index.php/jpd $\mathrm{pb} /$ article/view/14003.

Zainiyati, Husniyatus Salamah. Pengembangan Media Pembelajaran Berbasis ICT, Konsep Dan Aplikasi Pada Pembelajaran Pendidikan Agama Islam. Bandung: PT Kharisma Putra Utama, 2017. 